\title{
УДК:581.1:581.5:633.1 https://doi.org/10.53040/gppb7.2021.21
}

\section{ДИНАМИКА НАКОПЛЕНИЯ ХЛОРОФИЛЛА В ЛИСТЬЯХ Triticum aestivum L. В ЗАВИСИМОСТИ ОТ ГЛУБИНЫ ЗАЛЕГАНИЯ УЗЛА КУЩЕНИЯ}

\author{
Платовский Николай \\ Институт генетики, физиологии и защиты растений, Кишинэу, Республика Молдова \\ e-mail: nicolai.platovschii@igfpp.md
}

\begin{abstract}
This research paper presents the results of the dynamics of the accumulation of the chlorophyll index in winter soft wheat plants, depending on the depth of the tillering node. In conditions of lack of moisture, the deepening of the tillering node leads to the development of roots in more moisture-rich soil horizons, which reduces the risk of cultivating winter soft wheat. With the help of the chlorophyll index, it was possible to evaluate the effect of the deepening of the tillering node in the soil, as well as to assess the condition of plants and the rate of maturation.
\end{abstract}

Key words: Triticum aestivum L., индекс хлорофилла, хлорофилл, узел кущения.

\section{Введение}

На сегодняшний день исследование структуры и физиологического состояния фотосинтетического аппарата растений, оптимальных условий активности и качественной направленности представляет высокий интерес и перспективность изучения фотосинтеза. В ходе своего развития не только целое растение претерпевает закономерные изменения, но и все его части. Таким образом, становится необходимым исследовать фотосинтетическую активность на протяжении всего онтогенеза растения.

Главным компонентом фотосинтетического аппарата является хлорофилл, и исследования, связанные с биосинтезом и функциональной его активностью, имеют первостепенное значение. Благодаря работам $[8,4,9]$ были установлены пути синтеза хлорофилла, его роль в улавливании солнечного света, установлена роль минерального питания в синтезе и качественном составе хлорофилла. Результаты проделанных экспериментов показали, что количество хлорофилла в листьях и целом растении постоянно изменяется с возрастом, а также под влиянием различных условий внешней среды. Согласно литературным данным, в начальный период роста растений количество хлорофилла возрастает в связи с быстрым увеличением зеленой массы растения.

На фоне изменения климата в сторону увеличения температур становится необходимым разрабатывать новые технологии возделывания сельхоз культур. С возникновением новых подходов к возделыванию культур возникает необходимость в оценке состояния растений [6]. Среди множества подходов в решении данной задачи, нами принималось в большей степени исследование состояния фотосинтеза. Данный подход крайне актуальный в связи с тем, что именно фотосинтез определяет многие процессы развития растения, но также при этом является весьма чувствительным к малейшим изменениям условий среды [1], что дает возможность использовать его как индикатор состояния растительного организма при изменении условий среды. [7]. Для снижения рисков возделывания озимой мягкой пшеницы (Triticum aestivum L.) нами проводилась предпосевная обработка семян биорегулятором Реглалг [3], приводящая к заглублению узла кущения в почве [5]. Целью данной работы служила оценка влияния заглубления узла кущения на динамику накопления хлорофилла в онтогенезе и возможность оценки состояния развития пшеницы.

\section{Материалы и методы}

Для проведения исследований были отобраны 8 генотипов пшеницы: 5 сортов Молдавской (Молдова 5, Молдова 77, Молдова 11, Лэутар, Молдова 614), и 3 сорта Украинской селекции (Писанка, Куяльник и Эпоха), выращенные на опытном поле Института генетики, физиологии и защиты растений Республики Молдова. Высев проводился в первой декаде сентября при норме 5,6 млн. шт. сем./ на 1 га и глубине посева 5-6 см. Перед посевом семена обрабатывались биологически активным веществом Реглалг в концентрации 1/200. Определение индекса хлорофилла на площади посева проводили с помощью хлорофиллометра СМ-1000 (Германия), способного измерять ин- 
декс хлорофилла от 0 до 999 на расстоянии до 1,5 м на площади 11,8 см с точностью воспроизводимых показаний $\pm 5 \%$. Для определения количественного содержания пигментов хлорофилла $a$ и $b$ использовали 100\% ацетон согласно методике, описанной в [10] с модификацией по [11].

Исследования проводились в трехкратной повторности. Для извлечения хлорофилла использовали 10 испытуемых растений каждого варианта. Математический анализ результатов проводился согласно методике Доспехова полевого опыта [2] в программе Microsoft Excel 2007.

\section{Результаты и обсуждение}

На рис. 1 представлены результаты измерения содержания индекса хлорофилла на площади посева двух сортов контрольных и опытных вариантов, где можно отследить динамику накопления и убывания хлорофилла в зависимости от фазы развития растений.

Начиная с момента выхода из покоя - конец зимнего покоя, растения пшеницы начинают усиленно наращивать вегетативную массу, что ярко прослеживается на динамике накопления хлорофилла. Максимальный пик накопления хлорофилла начинается в начале стадии цветения и резко снижается по завершению данной фазы. Рисунок 1 можно разделить условно на 3 составляющие, когда идет усиленное накопление хлорофилла, состояние плато и убывание хлорофилла. Благодаря данному разделению можно проанализировать не только скорость наращивания биомассы, но также разработать агроприемы, направленные на уменьшение действия пагубных факторов внешней среды. Подчеркнем, что благодаря данной работе становится возможным разделить сорта по срокам созревания.

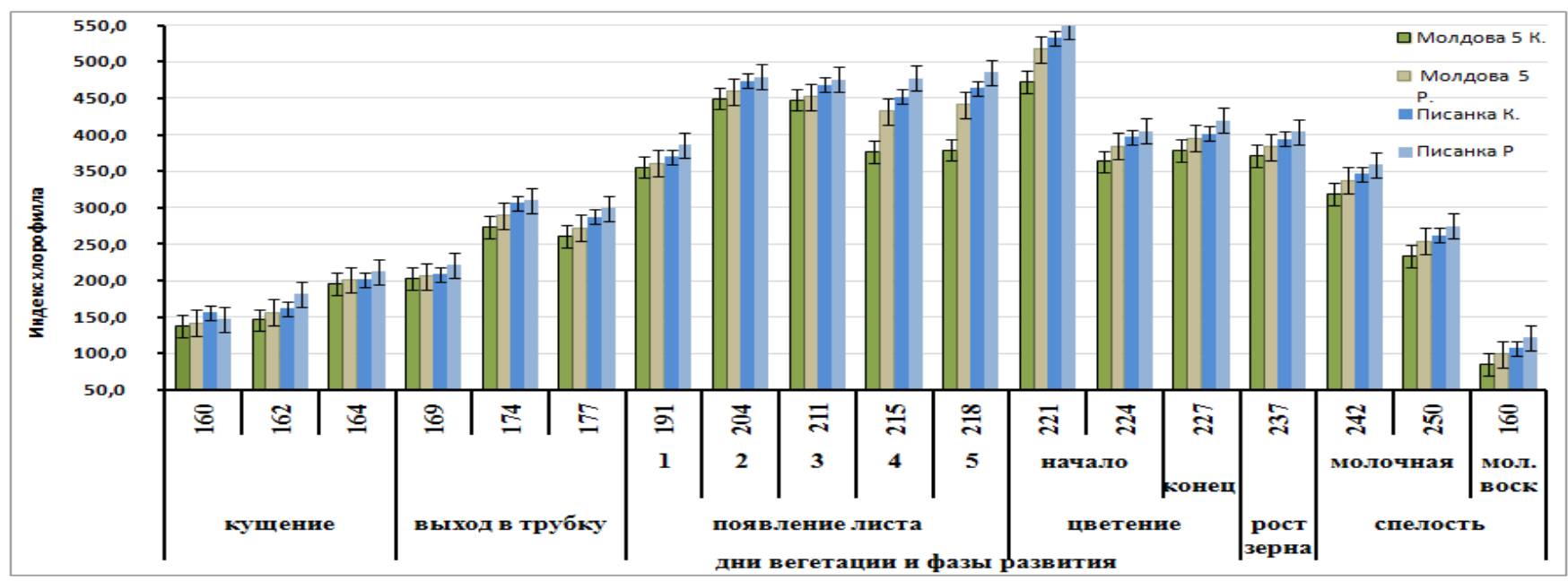

Рис. 1. Динамика накопления индекса хлорофилла, на площади посева пшеницы начиная с выхода из зимнего покоя, до молочно восковой спелости семян Triticum aestivum L. сортов Молдова 5 и Писанка двух вариантов (контроль и обработанные Реглалгом).

Благодаря применению биологически активных веществ, таких как Реглалг, происходит заглубление узла кущения глубже в почву, где влагообеспечение корней выше, что создает благоприятные условия для роста и развития растений и, как результат, вегетационный период у них растягивается, по сравнению с контролем. Данную задержку вегетационного периода регистрировали с помощью индекса хлорофилла. Метод можно использовать, как современный подход в определении скороспелости различных сортов.

Результаты, представленные на рис. 2, более подробно характеризуют разницу между двумя сортами по силе роста и состоянию флагового листа. Анализ содержания хлорофилла, $a$ по отношению к хлорофиллу $b$ дает возможность оценить состояние растений, в частности флаговый лист. Чем выше разница между хлорофиллом $a$ и $b$, тем эффективнее работает фотосинтетический аппарат листовой поверхности. Применение биопрепарата Реглалг, как видно из рис.2., приводит к увеличению разницы между соотношением хлорофилла $a$ к $b$. 


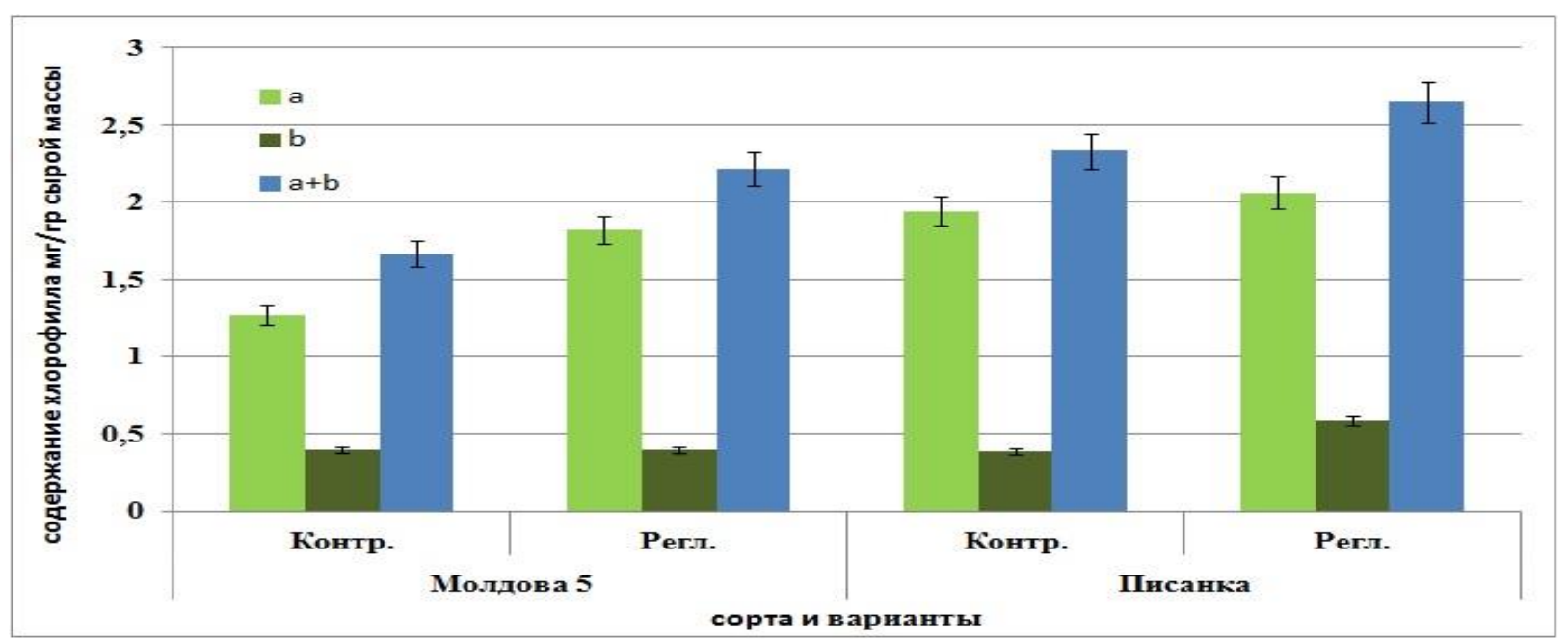

Рис. 2. Концентрация хлорофилла $\mathrm{a}, \mathrm{b}$ и суммы хлорофилла $\mathrm{a}+\mathrm{b}$ в флаговом листе растений Triticum aestivum L сортов Молдова 5 и Писанка в фазе молочной спелости.

Особое внимание хочется уделить содержанию суммы хлорофилла $\mathrm{a}+\mathrm{b}$ двух сортов свидетельствуя о том, что сорт Молдова 5 является более раннеспелым, по сравнению с сортом Писанка. Данный вывод можно сделать, совместив данные, представленные на рисунках 1 и 2 , так как на данной фазе развития флаговый лист уже полностью сформировался и в дальнейшем прирост хлорофилла не происходит (рис.1.). Применение биологически активного вещества Реглалг приводит к увеличению содержания хлорофилла, в частности хлорофилла $a$, по сравнению с контролем. Увеличение объясняется тем, что узел кущения залегает в более глубоких горизонтах почвы, и растения развиваются в благоприятных условиях, тем самым задерживая свой вегетативный период как минимум на $1-2$ дня дольше.

\section{Выводы}

В условиях неуклонного увеличения среднегодовой температуры, и сокращения дождливого периода, растения пшеницы все чаще подвергаются действию засухи. Для снижения действия неблагоприятного фактора внешней среды в Лаборатории Биохимии растений Института Генетики, Физиологии и Защиты растений был разработан биологически активный регулятор роста Реглалг, который как отмечалось раннее приводит к уменьшению длины эпикотиля, тем самым заглубляя узел кущения в более глубокие горизонты почвы. Благодаря достижению данного эффекта, удается снизить риск нехватки влаги в почве в период роста и налива зерна. Индекс хлорофилла служит хорошим индикатором состояния растительного организма, способного оценить не только отдельную его часть, но и в целом плантацию растений. Благодаря этому можно предсказать состояние посевов, начиная с момента выхода из зимнего покоя и вплоть до момента формирования колоса.

Уменьшение длины эпикотиля и заглубление узла кущения глубже в почву приводит к более быстрому росту индекса хлорофилла в начальный период развития растений, а также задержке вегетативного периода в конце жизни растений.

С помощью определения индекса хлорофилла в динамике времени становится возможным не только дать оценку состоянию различных генотипов озимой пшеницы, но также определить и скорость созревания различных генотипов.

Исследования проведены в рамках проекта Государственной Программы 20.80009.7007.07 «Определение параметров, характеризующих устойчивость растений с разным уровнем организации к действию экстремальных температур с целью уменьшения влияния климатических изменений», финансируемой Национальным Агентством по Исследованиям и Развитию Республики Молдова. 


\section{Литература}

1. БУХОВ, Н.Г., ДЖИБЛАДЗЕ, Т.Г. (2002). Влияние повышенных температур на фотосинтетическую активность у интактных листьев ячменя при низких и высоких освещенностях. Физиология растений. т. 49. c. 371-375.

2. ДОСПЕХОВ, Б.А. (1985). Методика полевого опыта (с основами статистической обработки результатов исследований). 5-е изд. доп. и перераб. - М.: Агропромиздат, с.351.

3. ЖЕЛЕВ, Н.Н., ДАСКАЛЮК, А. П. (2019). Влияние природного регулятора роста реглалг на устойчивость растений озимой пшеницы Triticum aestivum L. к низким экстремальным температурам. Агрохимия, №6, c.34-43. DOI: $10.1134 / \mathrm{S} 0002188119040136$.

4. НИЧИПОРОВИЧ, А.А. (1974). Хлорофилл и фотосинтетическая продуктивность растений. Хлорофилл. Наука и Техника. Минск, с. 49-62.

5. ПЛАТОВСКИЙ, Н. (2020). Влияние биостимулятора реглалг на термоустойчивость растений пшеницы Triticum aestivum L. Journal of Academy of Sciences of Moldova Life Sciences, Chisinau, Nr. 1(340), p.6369. ISSN 1857-064X.

6. ПЛАТОВСКИЙ, Н.Н., ЗДИОРУК, Н.В., РАЛЯ, Т.Х. (2021) Индекс хлорофилла как показатель роста, развития и продуктивности различных генотипов озимой пшеницы (Triticum aestivum 1.). Селекція зернових та зернобобових культур в умовах змін клімату:напрями і пріоритети: тези доповідей міжнародної наукової конференції (5 травня, СГІ-НЦНС, м. Одеса, Україна). с.183-184

7. ПЛАТОВСКИЙ, Н., ЗДИОРУК, Н., РАЛЯ, Т. (2020). Применение метода флуориметрии для оценки первичной теплоустойчивости флаговых листьев гексаплоидной пшеницы в зависимости от температуры теплового шока. Buletinul AŞM. Ştiinţele vieţii. Nr. 2(341), p.67-72. ISSN 1857-064X

8. ТЕРЕНТЬЕВ, В.М., ГОЛОВНЕВА, Н.Б., ФЕДЮНЬКИН, Д.В, КОШЕЛЕВА, Л.Л., СИДОРОВА, Т.В. (1974) Зависимость накопления фотосинтезирующих пигментов в листьях растений от спектрального состава и интенсивности света. Хлорофилл. Наука и Техника. Минск. с. 340-349

9. ШЛЫК, А.А. (1974)Развитие современных представлений о биосинтезе и состоянии хлорофилла. Хлорофилл. Наука и Техника. Минск. с. 3-15.

10. ШУЛЬГИН, И.А., НИЧИПОРОВИЧ, А.А. (1974). Расчет содержания пигментов с помощью номограмм. Хлорофилл. Наука и Техника. Минск. с. 127-138.

11. CARPENTIER, R. (2004). Photosynthesis Research Protocols Humana Press Inc., p.350. ISBN 1-58829-232-0 